International Journal of Agriculture, Environment and Bioresearch

Vol. 5, No. 03; 2020

ISSN: $2456-8643$

\title{
APPLICATION OF COCONUT SHELL CHARCOAL ON GROWTH AND YIELD OF UPLAND RICE
}

\author{
Betty Natalie Fitriatin ${ }^{1}$, Muhamad Iqbal Kusma Sudana ${ }^{2}$ and Tien Turmuktini ${ }^{2}$ \\ ${ }^{1}$ Soil Science Department, Agriculture Faculty ofUniversitasPadjadjaran, Indonesia \\ ${ }^{2}$ Agriculture Faculty of Winayamukti University, Indonesia \\ https://doi.org/10.35410/IJAEB.2020.5505
}

\begin{abstract}
Efforts to improve soil fertility can be done through application of ameliorant such as coconut shell charcoal. This study aimed to study the effect of coconut shell charcoal on the growth and the yield of upland rice. This experiment was carried out at the farmers 'field in PasirTalang Village, Sumedang Regency, West Java Indonesia. This experiment used a Randomized Block Design (RBD) consisting of six treatments and four replications. The treatments applied doses of coconut shell charcoal $(0,1,2,3,4$ and $5 \mathrm{t}$ ha-1). The results show that the application of coconut shell charcoal affected significantly on plant height at 10th day after planting (DAP) and 20th DAP. The application of coconut shell charcoal into soil increased root-shoot ratio, number of tillers and the yield of upland rice. The dose of $4 \mathrm{t}$ ha-1of coconut shell charcoal showed the highest increase in the yield of upland rice.
\end{abstract}

Keywords: Charcoal, coconut shell, ameliorant, upland rice.

\section{INTRODUCTION}

Rice (Oryza sativa L.) is an important crop that has become a staple food for more than half of the world's population. The food needs, especially rice, will increase in line with the increasing number of population. Planting rice on dry land can be alternative to increase rice production for food supply. The limiting factors of farming on dry land are low soil fertility caused by low soil organic matter, low nutrient content, and water availability.

One of the agricultural wastes that can be used as ameliorant is coconut shell charcoal (Erlinda et al. 2014). It contains nutrients such as phosphorus, potassium, sodium, magnesium, and other nutrient elements. Potassium element in coconut shell charcoal has a composition of $45.01 \%$ which can be used as a substitute for potassium from inorganic fertilizer (Sudding and Jamaluddin, 2016). Mongo et al. (2020) reported the positive effect of the coconut shell charcoal on the growth rate and feed conversion of the broilers. The application of coconut shell biochar ameliorant increased soil organic-C, cation exchange capacity (CEC), and yield of paddy rice(Herlambang et al. 2020)

The application of coconut shell charcoal aims to improve soil physical, chemical and biological properties, increase soil nutrient content, and decrease heavy metals contents (Winata et al. 2016).Sudding and Jamaluddin(2016) stated that application of coconut shell charcoal improved soil chemical properties, increased crop yields, reduced the loss of nitrogen from the soil, 
Vol. 5, No. 03; 2020

ISSN: $2456-8643$

reduced $\mathrm{CO} 2, \mathrm{CH} 4$ and $\mathrm{N} 2$ gas emissions, and was an alternative for mitigating the greenhouse effect. Liu et al. (2018) suggested that modified coconut shell biocharcould be used as an ameliorant to immobilize heavy metals in contaminated soils and improve soil physicochemical and biological properties.

The use of coconut shell charcoal as ameliorant was expected to support plant growth. Therefore, an experiment was carried out to determine the effect of coconut shell charcoal on growth and yield of upland rice.

\section{MATERIALS AND METHODS}

The experiment was carried out at the farmers' fieldin PasirTalang Village, Rancakalong District, Sumedang, West Java, Indonesia. The materials used in this experiment were upland rice (variety of Luhur 2), coconut shell charcoal, inorganic fertilizers consisting of Urea ( $46 \% \mathrm{~N}$ ) of $300 \mathrm{~kg}$ ha-1, super phosphate (36\% P2O5) of $100 \mathrm{~kg}$ ha-1, $\mathrm{KCl}(60 \% \mathrm{~K} 2 \mathrm{O})$ of $100 \mathrm{~kg} \mathrm{ha}-1$.

The experiment used the randomized block design (RBD) consisting of six treatments and four replications. The treatment applied doses of coconut shell charcoal $(0,1,2,3,4$ and $5 \mathrm{t}$ ha-1). The application of coconut shell charcoal was mixed with sheep manure as base fertilizer. Urea addition was given three times at 2, 4, and 6 weeks after planting. The application of super phosphate and $\mathrm{KCl}$ fertilizer was given only once at the beginning of planting. The upland rice was planted with a distance of $20 \mathrm{~cm}$ x $20 \mathrm{~cm}$.

The variables observed were plant height every ten dayuntil 60th days after planting, root-shoot ratio, number of tillers, and yield of upland rice (grain weight and 1000 weight).The observation of harvesting the yield was done at 120thDAP or when the plants have been ready to be harvested. Data were collected for analysis of variance (ANOVA) and treatment means were compared using Duncan's Multiple Range Test at $\mathrm{p}=0.05$ probability.

\section{RESULTS AND DISCUSSION}

The soil used in the experiment (Andisols) was considered as sub-optimal soil. The results of analysis show that the soilpH was 5.46, which is classified as acid criteria. The soil organic $\mathrm{C}$ (1.91\%), N-total (0.91\%), and C/N (10) were classified low, while soil P content (259.54 mg 100 g-1) and P-available (P2O5 Bray: $178.37 \mathrm{mg} 100 \mathrm{~g}-1)$ and K2O (178.37 (mg/100\%) were classified as very high. Furthermore, the cation exchange capacity or CEC (21.57 cmol kg-1) was classified as moderate. Based on the soil organic matter content, the soil in the experimental site had low organic matter content, therefore organic enhancers were needed to increase soil fertility.

This study showed that the application of coconut shell charcoal affected the growth of upland rice. Based on the statistical analysis, the plant height of upland ricewas significantly influenced by coconut shell charcoal at 10thday after planting (ADP) and20th ADP (Table 1). Observation of plant height at 10th ADP showed that coconut shell charcoal doses of $5 \mathrm{t}$ ha-1 increased plant height up to $10.2 \%$ compared to the control group. Whereas the application of coconut shell charcoal doses of $2 \mathrm{t}$ ha-1 increased plant height up to $10.5 \%$ at 20 th ADP. Wasis et al. (2018) 
reported the addition of coconut shell charcoal and compost significantly affected Agathisdammaraseedling growth (height, diameter, total wet weight, total dry weight, and rootshoot ratio).

Table 1 . Effect of coconut shell charcoal on plant height

\begin{tabular}{|rrrrrrr|}
\hline & \multicolumn{6}{c|}{ Day after planting } \\
\cline { 2 - 7 } Treatments & 10 & 20 & 30 & 40 & 50 & 60 \\
\hline $0 \mathrm{t} \mathrm{ha}^{-1}$ & $11,14 \mathrm{a}$ & $13,58 \mathrm{a}$ & $30,55 \mathrm{a}$ & $39,35 \mathrm{a}$ & $50,63 \mathrm{a}$ & $64,33 \mathrm{a}$ \\
$1 \mathrm{t} \mathrm{ha}^{-1}$ & $10,60 \mathrm{a}$ & $14,93 \mathrm{~b}$ & $33,91 \mathrm{a}$ & $39,88 \mathrm{a}$ & $50,30 \mathrm{a}$ & $65,02 \mathrm{a}$ \\
$2 \mathrm{t} \mathrm{ha}^{-1}$ & $11,03 \mathrm{a}$ & $15,00 \mathrm{~b}$ & $24,72 \mathrm{a}$ & $40,63 \mathrm{a}$ & $51,29 \mathrm{a}$ & $64,99 \mathrm{a}$ \\
$3 \mathrm{t} \mathrm{ha}^{-1}$ & $11,19 \mathrm{ab}$ & $14,04 \mathrm{a}$ & $24,46 \mathrm{a}$ & $54,80 \mathrm{a}$ & $52,89 \mathrm{a}$ & $65,44 \mathrm{a}$ \\
$4 \mathrm{t} \mathrm{ha}^{-1}$ & $12,21 \mathrm{~b}$ & $13,20 \mathrm{a}$ & $26,06 \mathrm{a}$ & $41,45 \mathrm{a}$ & $51,11 \mathrm{a}$ & $64,68 \mathrm{a}$ \\
$5 \mathrm{t} \mathrm{ha}^{-1}$ & $12,28 \mathrm{~b}$ & $14,21 \mathrm{ab}$ & $25,61 \mathrm{a}$ & $40,92 \mathrm{a}$ & $51,47 \mathrm{a}$ & $64,56 \mathrm{a}$ \\
\hline
\end{tabular}

Note : The average value followed by the same letter is not significantly different according to Duncan's Multiple Range Test at the level of 5\%.

The application of coconut shell charcoal affected root-shoot ratio, number of tillers, and yield of upland rice (Table 2). Root-shoot ratio reflects photosynthetic allocation between shoot and root. The root has important role for nutrient and water absorption. Based on the statistical analysis, treatment of $4 \mathrm{t}$ ha-1and $5 \mathrm{t}$ ha-1ha of coconut shell charcoal increased root-shoot ratio significantly. The application of coconut shell charcoal at doses of 4-5 tha-1increased root-shoot ratio by 135-140\% compared to the control group. The increase in plant growth with biochar application has been reported for another plant. Wasis et al. (2018) stated that coconut shell charcoal and compost incorporation into soil affected root-shoot ratio of Agathisdammara. Result of study by Egamberdieva et al. (2016) indicated that biochar as soil amendment increased growth of soybean. Whereas, Wasis and Istantini(2013) reported application of coconuts shells charcoal and cow manure enhanced seedling growth of jabon (AnthocephaluscadambaMiq.)

Table 2. Effect of coconut shell charcoal on shoot root ratio, number of tillers and yield of upland rice

\begin{tabular}{|ccccc|}
\hline Treatments & $\begin{array}{c}\text { Shoot root } \\
\text { ratio } \\
\text { (SRR) }\end{array}$ & $\begin{array}{c}\text { Number of } \\
\text { tillers }\end{array}$ & $\begin{array}{c}\text { grain } \\
\text { weight }(\mathrm{g})\end{array}$ & $\begin{array}{c}1000 \\
\text { weights }(\mathrm{g})\end{array}$ \\
\hline $0 \mathrm{t} \mathrm{ha}^{-1}$ & $0,99 \mathrm{a}$ & $10,90 \mathrm{a}$ & $16,65 \mathrm{a}$ & $18,44 \mathrm{a}$ \\
$1 \mathrm{t} \mathrm{ha}^{-1}$ & $1,28 \mathrm{a}$ & $10,95 \mathrm{a}$ & $16,74 \mathrm{ab}$ & $20,26 \mathrm{ab}$ \\
$2 \mathrm{t} \mathrm{ha}^{-1}$ & $1,06 \mathrm{a}$ & $11,05 \mathrm{a}$ & $17,66 \mathrm{a}$ & $22,52 \mathrm{~b}$ \\
\hline
\end{tabular}




$\begin{array}{lrrrr}3 \mathrm{t} \mathrm{ha}^{-1} & 1,67 \mathrm{ab} & 11,95 \mathrm{~b} & 20,85 \mathrm{bc} & 22,54 \mathrm{~b} \\ 4 \mathrm{tha}^{-1} & 2,33 \mathrm{~b} & 11,75 \mathrm{~b} & 25,46 \mathrm{~d} & 23,59 \mathrm{c} \\ 5 \mathrm{t} \mathrm{ha}^{-1} & 2,38 \mathrm{~b} & 11,55 \mathrm{ab} & 22,49 \mathrm{c} & 22,95 \mathrm{bc}\end{array}$

Note : The average value followed by the same letter is not significantly differentaccording to Duncan's Multiple Range Test at the level of 5\%.

Table 2 shows coconut shell charcoal at dose of $3 \mathrm{t}$ ha-1 significantly increased the number of tillers of $9 \%$ compared to the control group. This value was smaller than the root-shoot ratio which increased more than $100 \%$.

In this study, the application of coconut shell charcoal increased yield of upland rice. This is probably due to the charcoal characteristics has much pores which are very effective to increase and store nutrients. Some studies reported that coconut shell charcoal has function as an ameliorant for increasing the soil characteristics (soil physic, soil chemical, and soil biology). Zhao et al. (2019) reported coconut shell increased the biomass yields of water spinach and reduced the leaching nitrogen loss.

Table 2 showsthe application of coconut shell charcoal at doses of $4 \mathrm{t}$ ha-1 increased grain weight by $52.9 \%$ and increased 1000 weights by $27.9 \%$ compared to the control group. Furthermore, the dose of $4 \mathrm{t}$ ha-1 of coconut shell charcoal was the best treatment affecting the yield of upland rice.

\section{CONCLUSION}

The results of this study show the application of coconut shell charcoal as soil ameliorant affected the growth of upland rice. The coconut shell charcoal affected significantly on plant height at 10th day after planting (DAP) and 20th DAP. Therefore, it can be concluded that the application of coconut shell charcoal into soil increased root-shoot ratio, number of tillers, and yield of upland rice. Furthermore, the dose of $4 \mathrm{t}$ ha-1 of coconut shell charcoal increased the highest the yield of upland rice.

\section{Acknowledgements}

This research was supported by grants received (applied research :021/UN6.E/LT/2019) from the Directorate General of Higher Education Ministry of Research and TechnologyIndonesia. We thank to staff Laboratory of Soil Biology, and also to our studentDzakariaYogaswarafor his cooperation.

\section{REFERENCES}

Egamberdieva, D., S.Wirth, U. Behrendt, EF. Abd_Allah and G. Berg. 2016. Biochar Treatment Resulted in a Combined Effect on Soybean Growth Promotion and a Shift in Plant Growth 
Vol. 5, No. 03; 2020

ISSN: $2456-8643$

Promoting Rhizobacteria. Front.Microbiol.Vol 7 (209).https://doi.org/10.3389/fmicb. 2016. 00209

Erlinda, S., T.D. Boi, W. Futri and B. Esmar. 2014. Coconut Shell Activated Carbon as an AlternativeRenewable Energy. Renewable Energy and Energy Conservation Conference and Exhibition. ttps://knepublishing.com/index.php/KnE-Energy/article/view/360/1255

Herlambang, S., P.B. Santoso , H.R. Sutiono and S.R. Nugraheni. 2020. The application of biochar and organic matter for proper cultivation on paddy soil. Journal ofDegraded and Mining Lands Management.Vol.7 (3) : 2133-2137. DOI:10.15243/jdmlm.2020.073.21

Liu H, Xu F, Xie Y, Wang C, Zhang A, Li L, and Xu H, 2018. Effect of modified coconut shell biochar on availability of heavy metals and biochemical characteristics of soil in multiple heavy metals contaminated soil. Sci Total Environ. Vol.15 (645) :702-709.

Mongo B G, Ghomsi M O S, Tientcheu B L, Semi A Y, Menghueo T N and Etchu K A 2020 Effect of coconut (Cocosnucifera) shell charcoal on the growth performance of broilers. $\begin{array}{lllll}\text { Livestock } & \text { Research } & \end{array}$ (47).http://www.lrrd.org/lrrd32/3/ghoms32047.html

Suddingand Jamaluddin. 2016. The processing of coconut shell based on pyrolysis technology to produce reneweable energy sources. Proceedings of ICMSTEA3rd - 4th October 2016 : International Conference on Mathematics, Science, Technology, Education, and their Applications, Makassar, Indonesia,

Wasis, B., B. Winata and R. Andriani. 2018. Growth of Agathisdammara(Lamb. Rich.) seedling on gold tailing with addition of coconut shell charcoal and compost. Archives of Agriculture and Environmental Science. Vol. 3(2): 131-136

Wasis, B. and A. Istantini (2013). Application of coconuts shells charcoal and cow feces (bokhasi) on the growth of jabon (AnthocephaluscadambaMiq.) seedling at gold mine tailings medium. Journal of TropicaSilviculture Science and Technolo-gy, 04(2): 82-87

Winata, B., Wasis, B. and Setiadi, Y. (2016).Adaptability study of samama (Anthocephalusmacrophyllus) on several lead $(\mathrm{Pb})$ level.Journal of Natural Resources and Environmental Management, Vol,6 (2): 210-216,https://doi.org/10.19081/jpsl.2016.6.2.211

Zhao, F., G. Zou, Y. Shan, Z. Ding, M. Dai and Z. He. 2019. Coconut shell derived biochar to enhance water spinach (Ipomoea aquaticaForsk) growth anddecrease nitrogen loss undertropical conditions. Scientific Reports (2019) 9:20291. https://doi.org/10.1038/s41598-019-56663.. 